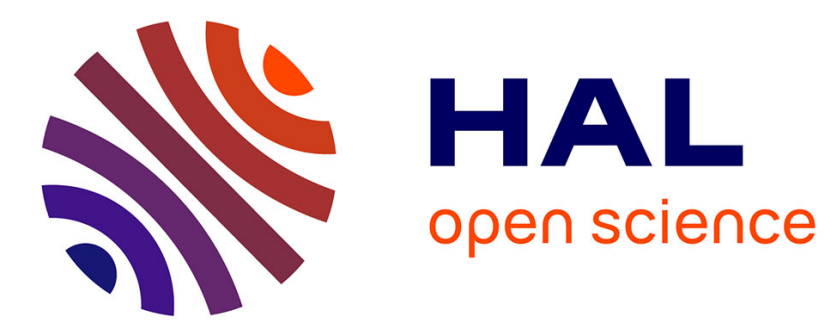

\title{
Looking for the social experience of mental illness \\ Livia Velpry
}

\section{To cite this version:}

Livia Velpry. Looking for the social experience of mental illness. Legitimidades da loucura. Sofrimento, luta, criatividade e pertença., EDUFBA, 2018. halshs-01953849

\section{HAL Id: halshs-01953849 \\ https://shs.hal.science/halshs-01953849}

Submitted on 26 Sep 2019

HAL is a multi-disciplinary open access archive for the deposit and dissemination of scientific research documents, whether they are published or not. The documents may come from teaching and research institutions in France or abroad, or from public or private research centers.
L'archive ouverte pluridisciplinaire HAL, est destinée au dépôt et à la diffusion de documents scientifiques de niveau recherche, publiés ou non, émanant des établissements d'enseignement et de recherche français ou étrangers, des laboratoires publics ou privés. 


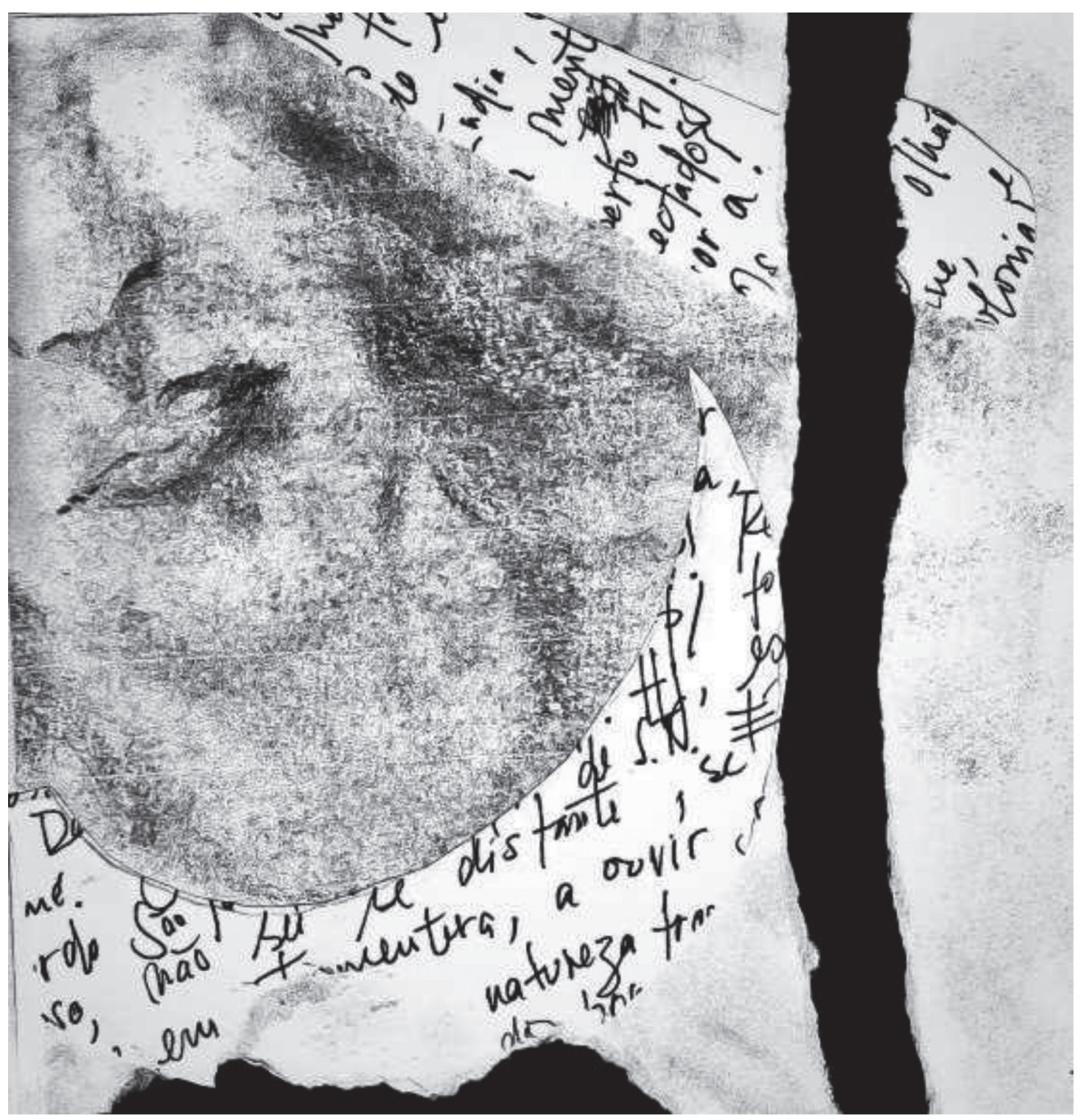

A loucura como experiência social 


\title{
Looking for the social experience of mental illness ${ }^{1}$
}

\author{
Livia Velpry
}

\section{Setting the scene}

\section{Coming in}

January 2002. It is $9 \mathrm{am}$. I am in the elevator of a Presbyterian Church in downtown Washington, DC. John is standing next to me. We don't talk, but he is smiling broadly, as he often does. His smile shows the hole of his two missing front teeth. He is a skinny and energetic man in his late sixties. We often share this elevator ride, me arriving for my day at the center, John coming back from his long morning walk. I like this brief, mostly silent encounter. John's smile feels like a welcome to the place, when I often arrive wondering why and what is going to happen. Seeing his smile also triggers a much more tenuous feeling, that we are both sensitive to the sweet irony of life.

When I come in the huge hall that is the center's day room, I spot Doris and Martha in the reading corner. They sit in their big chairs, next to the magazines. I go to them and say hi. We talk a little about daily news, how was the weekend, what is for lunch. Sometimes I get bored or even

Contribution for Mônica Nunes and Tiago Pires Marques (Eds.), Legitimacies of Madness. Suffering, Creativity, and Belonging. 
depressed by the sole sight of these two, because of how predictable our exchanges are. Yet, I feel compelled to go and talk with them, to adopt their chitchatting. I imagine they are expecting that from me because somehow I am here to be agreeable to them.

After greeting Lisa and Dan, the art therapist and the case manager, in the office room, I go and see Carryl, who is sitting motionless on a chair against the wall. He is waiting for me in a quiet, thoughtful way. Today we are to continue the interview session from last week. Once we are seated in the small meeting room, I turn on the recorder and he starts commenting on the story that he told me last time. He says he thought it over and that maybe he could have fought more when his wife left him. But that's how weak he was, and still is, he says, fatalistic. We then discuss cultural explanations for the differences in the treatment of mental illness in France and in the US. Judging from the intensity he puts into them, I sense that he seizes our moments together as a longed-for opportunity to reflect on past events.

A little less than an hour later, we end the discussion and we join a dozen other residents and Lisa in the activity room. Today we have planned a drawing session; the theme is: "drawing a life tree". This was Lisa's idea, which she suggested last week, when we discussed my project of working on the "life stories" of the residents. Yet, it is not clear to me, nor to her and to the others in the room, what exactly a "life tree" should be. For about an hour, everyone, including myself, tries to make something out of this vague instruction in his or her own way. As usual, John ignores it altogether and starts to write in small caps on the blank page. Today, his title is about God. It very often is. I don't know where all this is going.

\section{Giving back}

January 2003. I stand in the activity room of the McClendon center, alone, rubber and scissors out on the table, along with copies of drawings, pictures, writings made by Carryl, Doris, John and a few other residents. There is also the printed text I've edited from taped interview sessions and then discussed with each resident. I am assembling these bits of things produced during the past year, my selection, on folded cardboard. There is one 
such booklet for each resident I engaged with at the center. Today we have our last meeting; I'll give each one their booklet and we'll say goodbye.

Finally they come in; I've set the booklets on the table where our sessions took place. Each one takes their own; they look at it, show them to one another. I explain some of the choices I made. They smile. We take pictures. They look happy, yet I am not sure how much they care. I thank Lisa and Dan, too. When I leave, I take with me a paper copy of each booklet.

\section{Incomplete: the production}

These two scenes are emblematic of moments I spent in a day treatment center for older people with a history of severe mental illness. John, Doris and Carryl all engaged in the "life story project" I conducted there over a period of several months, along with five other residents.

Figure 1 - Delores' booklet

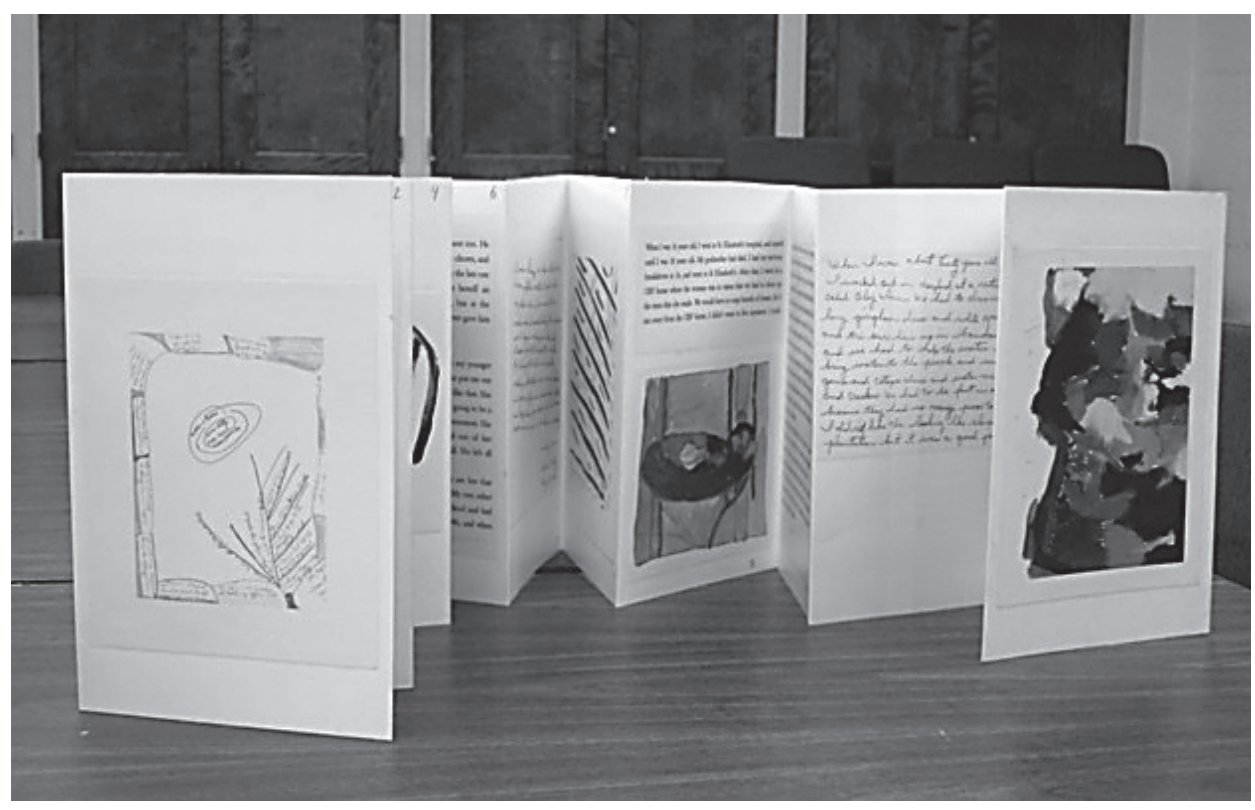

Source: 1/25, Portfolio (9 Jan. 2003).

Initially the project was quite vague; it took shape slowly. In retrospect, it consisted of eliciting stories and memories from residents during group sessions that I ran with Lisa, the energetic and unassuming art-therapist. 
The participants produced drawings and writings upon a suggested theme (draw a life tree, your first job, your first memory...). In parallel, I collected individual narratives through repeated interviews or informal discussions with the willing residents, during the day I spent at the center each week. After a few months, I gathered all sorts of material from the residents who happened to engage in the project and made a booklet for each of them. These booklets contained drawings from the art sessions, writings from the writing sessions, pictures, either personal or taken during special activities at the center, as well as a selection of excerpts from the story they had told.

The idea of making the booklets came to me rather late in the process. What I called the "life story project" started as an ill-defined attempt to explore other ways of approaching experience and the relationship with "informants". A doctoral student at the time, I was immersed in medical anthropologists' stimulating debates about experience, narratives and mental disorder. I was also conducting fieldwork in supported employment groups, both in outpatient mental health services and on the grounds of a semi-abandoned mental hospital. In these settings, my role as an ethnographer was better defined and the data I gathered more structured. In the Centre, though, I didn't feel comfortable coming regularly and meeting with the residents to learn about their lives, without thinking of a giveback of some sort. I also wanted to explore how to produce a narrative space that would not be reduced to a discourse, but rather incorporate other forms, context and depth of experience. Thus the multiple ways through which we engaged in the project: drawing and writing activities, chats, and formal interviews. The booklets then seemed a natural materialization.

Giving them to the residents was a way to return some of this to them. At the time, I felt it was also fair trade for the use I could make of the product of their time and engagement to write social science with. Yet, and to my own surprise, this experience remained encapsulated, isolated from the rest of my activities in research and mental health. The dissertation I wrote, as well as the papers I published in the following years about the experience of mental disorder and its narratives left the residents, their narratives and 
booklets completely out. Somehow, I was unable to transfer the experience into words.

Looking at it with some distance, it seems clear that making the booklet was not only a giveback. It also had a powerful effect on the whole process, because it shifted the locus of encounter. Because of this end product, our meetings were not aimed at gathering the data for my production on "life stories with a mental illness". Rather, they were bricks to be used in the fabrication of a self-sufficient object.

In a sense, there was no need to do anything more. Exchanging the booklets could stand as a satisfying closure of the project. Yet, during the years that followed, I kept returning to this experience with the uneasy feeling that something was left unfinished. It was still lingering a decade later, when I opened a box with the Xeroxed booklets. The booklets weren't enough. Something more needed to be said, to account for what had happened. This is what I set to do, while maybe also circling in on the reflection about mental disorder, experience and narrative that I had been developing in the meantime.

Figure 2 - Displayed booklets

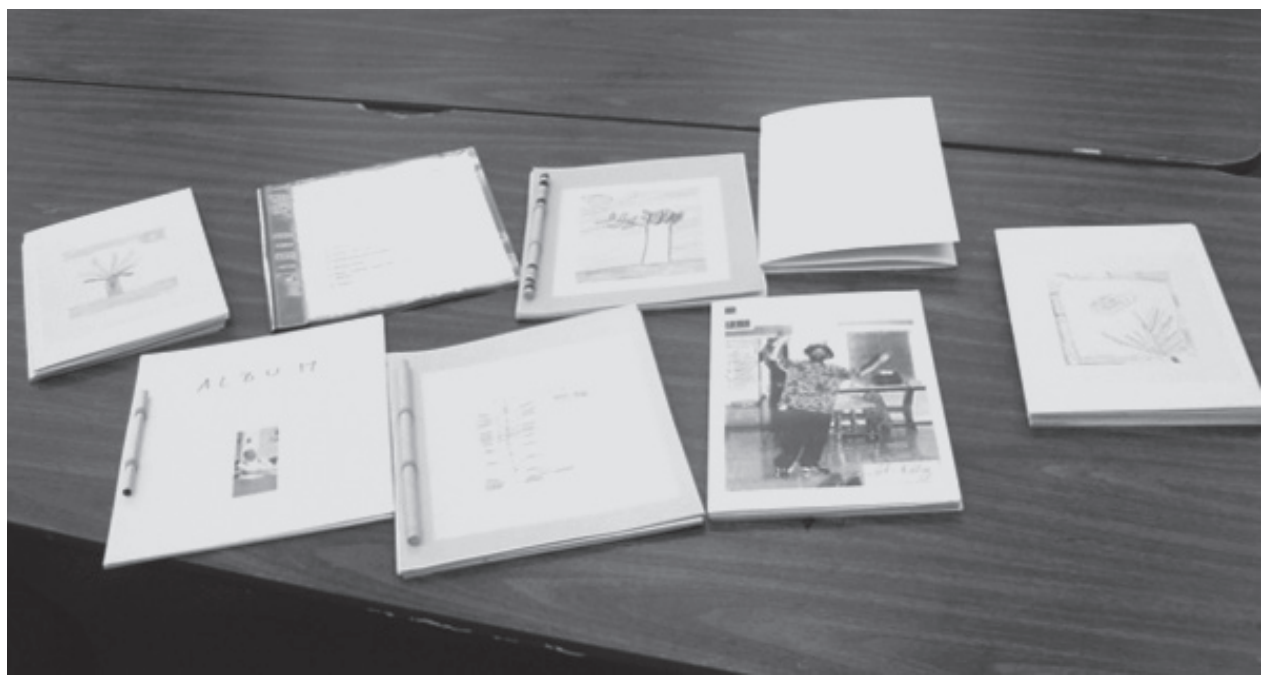

Source: 1/25, Portfolio (9 Jan. 2003). 


\section{Weaving the threads: overarching plots}

What is left of an ethnographically-oriented experience, when it hasn't been transformed into academic writing? Good manuals of ethnography rightly stress that without a trace (written notes, recording, drawings...), there is no observation. In this contribution, going through the traces of this encounter with older people whose mental disorder strongly impacted the lifecourse, I weave together several threads. Assuming that this account is always coproduced with the ethnographer in a situated encounter, I incorporate the rapport we engaged in as well as the form taken by the final product. In so doing, this text also builds up a more academic argument, taking hold of the notion of the social experience of mental illness, to help think through the contextual nature of experience and of its rendering. What happened with Carryl, Doris and John delineates key aspects of this context.

How does time affect not only the retrospective look on one's life but also on the experience itself? The story one tells about one's life is the result of multiple sorting operations, of what was told before, of what was forgotten, of what was never said and for some reason resurfaces; of rearrangements for coherence sake; of what it is possible to say to me, of what I seem to expect; of what our conversations lead us to explore interview after interview. Going back to this experience more than ten years later brought forward the same effects of time, leading me to take from this experience a mix of what was salient then and sharpened with time; of what is informed and shaped by my later experiences; and by the process of exhuming notes and trying to understand what happened at the time.

There might also be a more intimate motivation to the writing of this piece. I wish to convey Carryl, Doris and John's ways of being and of engaging with me, along with their story. I wish them to become interesting and moving enough to make the reader look at their drawings or read their words with the interest and empathy that one has for people we have connection with. It might stand as another way of giving back. 


\section{Coproducing an account of the past}

In order to characterize the narratives that Carryl, Doris and John produced, I tried to give a sense of how each appeared to me during our encounters, as well as of the relationship we developed. I also described the elements that composed each booklet. Finally, I look at their narrative trying to decipher how the resources, life domains, emotions and perceptions intertwine and shape it implicitly; but also looking at what are their questions or preoccupations of the day. These elements are a key to understand what needs to be remembered and told, from what is forgotten or silenced.

\section{Reflecting on one's past}

Carryl was tall and thin; he walked slowly, slightly bent, like an old man. He didn't chat but he did engage in discussions. During our long taped interviews, he seemed to find in me a partner to talk about culture and art, about history and philosophy.

He also seized the opportunity of our interviews to talk about his life and turned it into a tool for introspection. From one meeting to another, he would go back to an event and try out a different analysis. In other words, the space of discourse Carryl and I shared was reflexive.

His booklet contains three contributions by his hand. There is the Lifetree he drew: a column with two symmetrical leaves on each side, unevenly disposed, each numbered from year 1 to 12 . There is a short text, entitled "Life story", where he efficiently summarizes 77 years of his life, including locations, employment and religion - although he left out his failed marriage. A few sentences stand out in his rather clinical/factual account, like the fact that he's "drawing a check every month from Uncle Sam" or that although he does not attend church, he has "the spirit". Then there is another, even shorter text, describing much more vividly his first job collecting bills on his bicycle in the hot summer. A bunch of pictures provided by Lisa, show his long silhouette at or around the center. He's usually standing, still, sometimes with a sweet smile. 
But most of the many pages of Carryl's booklets are the transcript or our interviews, where he details at length the events of his life, incorporating reflections about causes, turning points, looking for explanations for the turn of events, trying to understand who he was but also carefully depicting the many characters.

Figure 3 - 'Draw a lifetree'

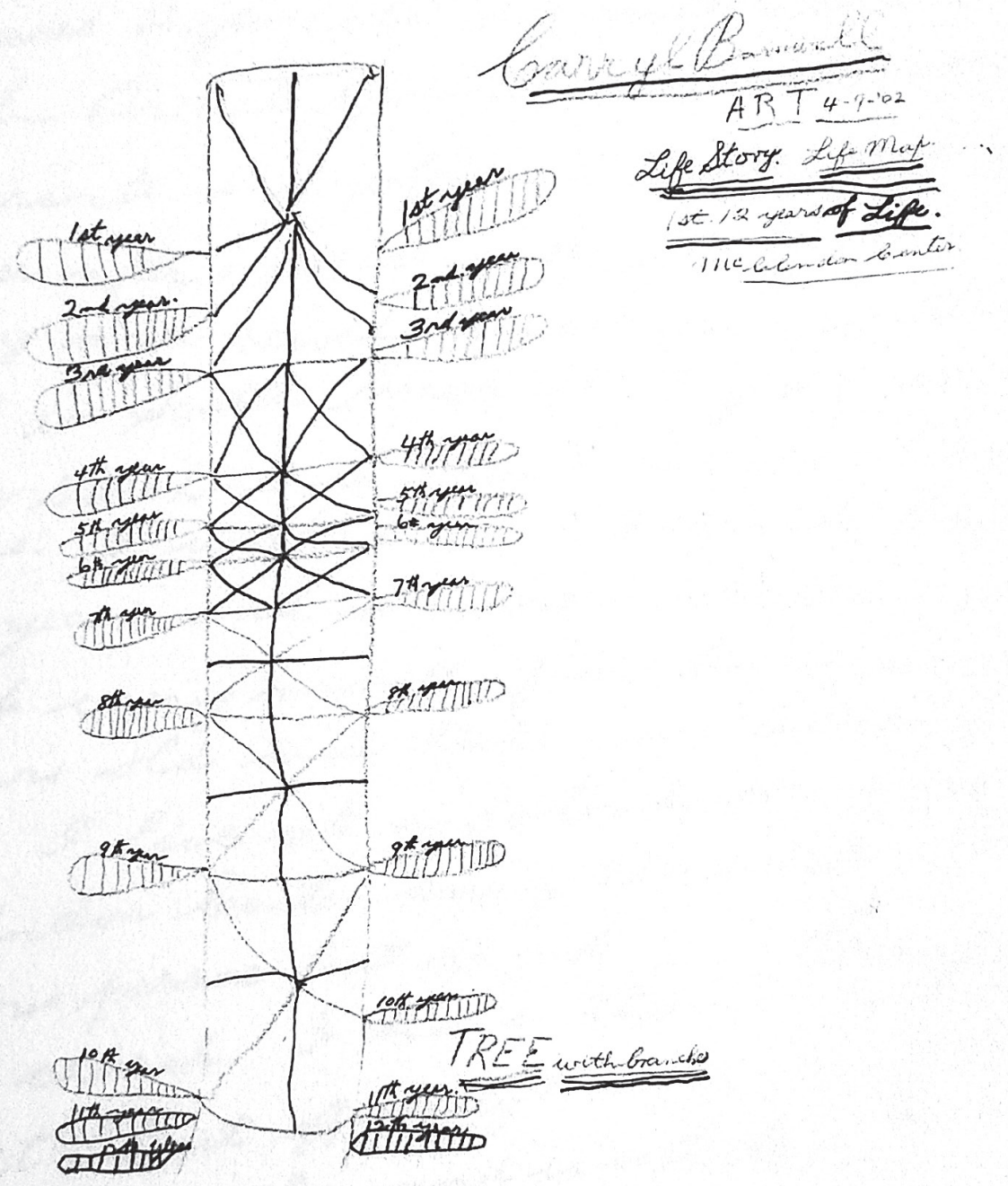

Source: excerpt from Carryl's booklet, author's own copy. 
The issue of the illness is intertwined with the other life issues. Although as he describes it, the illness is not the central feature of his life, in his narrative he keeps commenting on how the illness affected the course of his life.

Figure 4 - Carryl in the main room

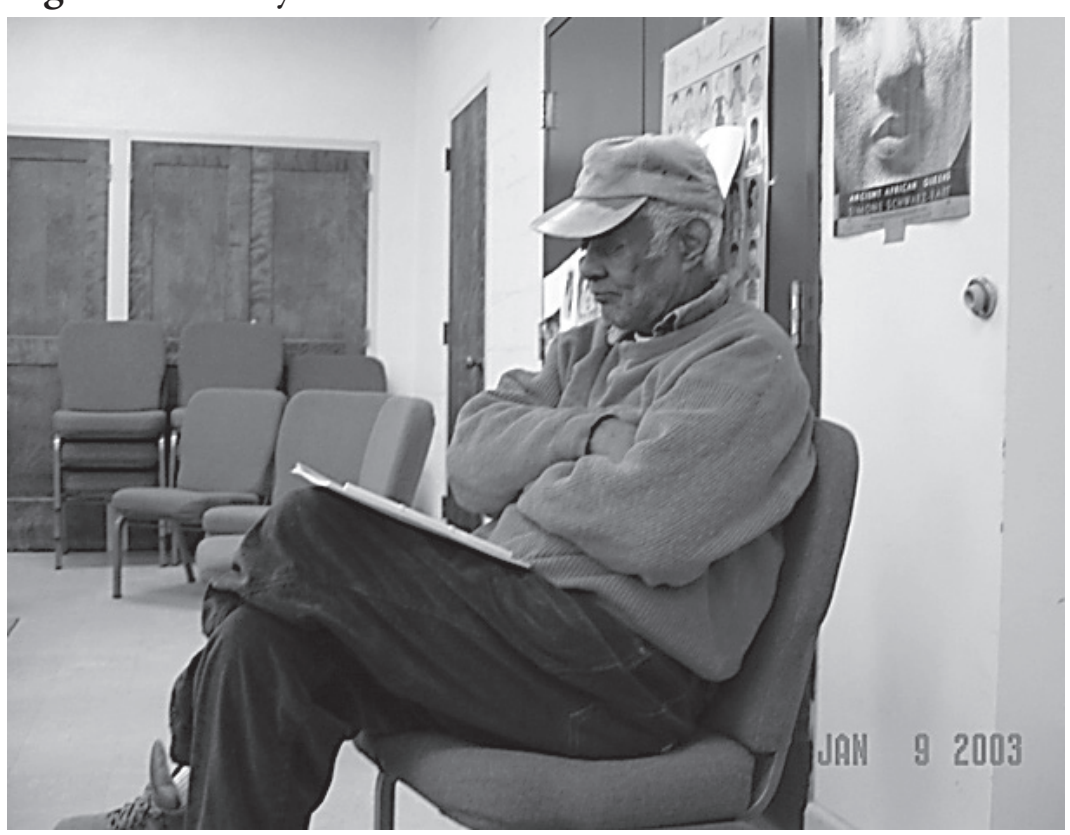

Source: 17/25, Portfolio (9 Jan. 2003).

\section{An origin for his problem?}

Carryl's story starts with his childhood in British Guyana. Although he was born in the US, his mother took him and his younger brother back to his grandparents after her divorce. Raised in a poor household, he nonetheless got the opportunity to go to high school because of his good grades and of his grandfather's pressure, but he had to stop and work at age 16. His mother kept her clerical job in Seattle and he didn't see her again until he joined her at age 18.

Remembering vividly his arrival to the US, he commented on his discovery of the contrast between what he called the aggressiveness of US African-American/blacks, and his own passive attitude toward life. He related this attitude to the way black people were in Guyana, submissive 
to the British and the Queen and knowing their place. His narrative continued with the short time he spent in the army, not in combat, which offered him an opportunity to study psychology at the university, through the GI Bill. ${ }^{2}$

The story of his two short-lived marriages and of his moving from the West Coast to the East Coast were intertwined with his growing estrangement from life, which is how he described his disorder, as with the various hospitalizations that ensued.

\section{The inexorable loss of resources}

One of Carryl's recurring interrogations in his account of his past was to wonder whether and how his life could have been different, without the illness. It is interlaced with a "typical" severe mental illness narrative of the progressive loss of his social inscriptions and the subsequent adjustments: his wife divorcing him as he was hospitalized because "she had to go on with her life", him having to quit his job and his mother then helping him find supported employment...

Also typical is his progressive integration into a supported mode of living, from the 30 years long janitor position he had at the hospital to the supportive housing and the 10 cigarettes and one dollar a day regime he complied to, commenting that he had become too dependent to live on his own.

\section{Why?}

Another question he asks is why the illness, why did it happen to him. As he describes his life, he raises several hypotheses, such as the fact that his grandparents raised him, or that his mother left him when he was very young and that he grew up without seeing her, only reading her frequent letters, or else his "weakness" of character in an aggressive country, among other reasons.

2 The G.I. Bill refers to the Serviceman's Readjustment Act of 1944 that provided education benefits - among many others - for veterans returning from World War II. 
Figure 5 - Quote from Carryl's lifestory

\title{
Carryl
}

\begin{abstract}
"After the divorce with my first wife, I met a young 17 years old, I was 27 at the time, and I got married to her. I had another baby with her, Gwendolyn. I didn't do right with any of my wives. They were glad to see me go, I guess. I didn't have real passion for nobody. So they probably sensed that. Maybe I was a mama's boy, I guess that's what it was. The influence of the mother I guess is strong in certain men."
\end{abstract}

Source: personal files.

In Carryl's questions appear the intricate influences of illness and life opportunities in accounting for his current situation. At various points in his life, his expectations were deflected; they had to be reevaluated according to what was within the range of the possible. This happened once when he had to renounce the unexpected opportunity to go to high school, given by his teachers, in order to work. His second chance comes as a young man living in the US, when the GI Bill opens the doors of the university for him. Yet, here again, probably because of the manifestations of what will become his illness, he cannot continue. This leads him to present himself as satisfied today, although he underscores that he is now dependent with no hope of this ever changing.

\section{Fighting for survival}

Carryl didn't really get along with Doris, who was a character in the center. She spoke too loudly for him and was endlessly opinionated. She also appeared limited, which was reinforced by her childish manners. Our formal interviews were short; she seemed to be uncomfortable with them, maybe because she had few and scattered memories to offer in the face of my questions. Many of her memories were so blurred that they seemed to melt. What we did was have long chitchatting sessions, where she would 
comment at length on given episodes of her life, telling a story of hardships, fights and survival. When we conversed, Doris called me "honey" every other sentence. She treated me as a granddaughter, using her life story both to give me an idea of how things were in her time and to give me sound advice. Our unspoken arrangement was about transmission.

Figure 6 - 'When I was a little child'

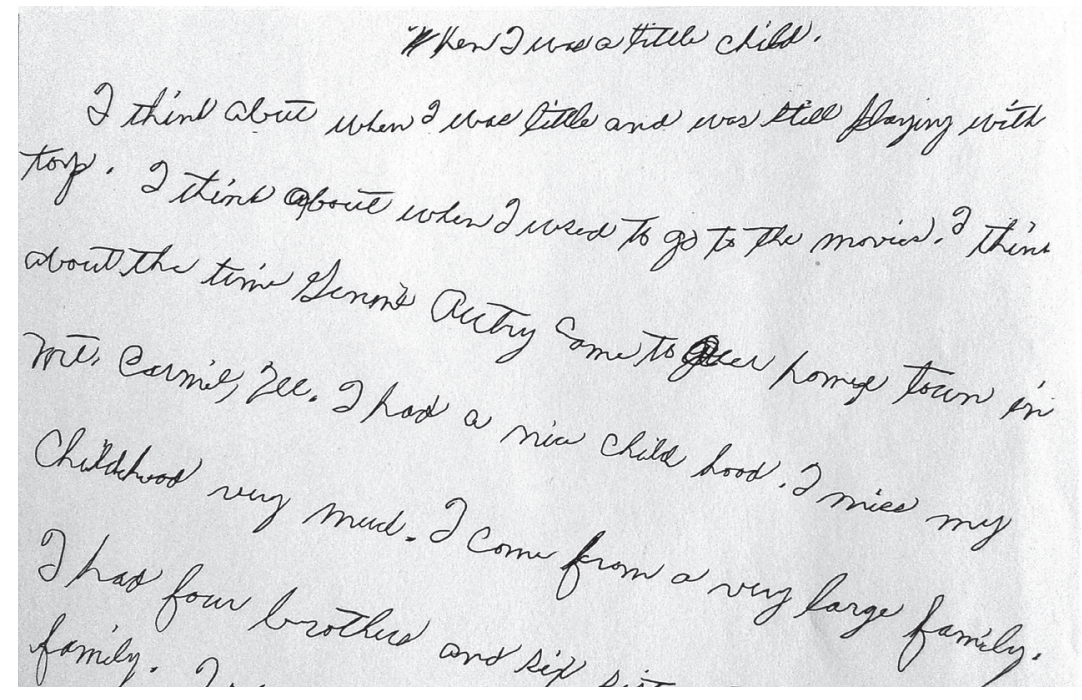

Source: excerpt from Doris' booklet, author's own copy.

Figure 7 - Quote from Doris' lifestory

So where do we storf?

Well, honey, do we start at birth?

As you want

Well, honey, I was born in 1929, start of

Depression, in Southern Illinois. Mounl Carmel.

And, honey, it's a holy lown and it's

beautiful. (...) And, honey, I lived there till I

was 30 years old. honey. And then I came up

here. And, honey, I am glad I come up here.

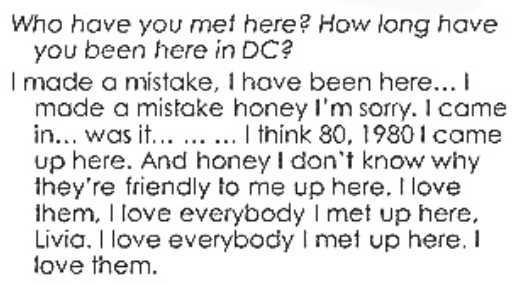

Source: excerpt from Doris' booklet, author's own copy.

Doris' booklet is really thick, about 40 pages long. It includes two short writings from our collective sessions, as well as a few drawings. Graves appear on two of them. Opening and closing the booklet are two versions of the same 
drawing/engraving of a tree with the sun in the upper left corner. The texts are hard to read because of the clumsy writing. In both she writes "I miss my childhood very much". In fact she does seem to enjoy girlish talk, keeping things and discussions on the most superficial level. Yet the childhood she recounts during our repeated chats doesn't bring only good memories.

I also included a few pictures taken at the center. Unlike Carryl, who is sitting or standing in the room, alone, in these pictures Doris is usually taking the pose for an event. She has the smile of a little girl and the shape of an older, plump woman. The rest of the booklet displays her account of her life, which for some reason I printed using a very large font size. I wonder today if by doing so I was attempting to match her self-presentation as a simple, almost limited older woman. Although I left out our dialogues from the text, it retains her calls to me, as well as her dynamic spoken style. As in "Did I tell you the doctor said when I was born, if I was to live to 14 years old it would be a miracle?".

Figure 8 - Doris and Martha with their booklets

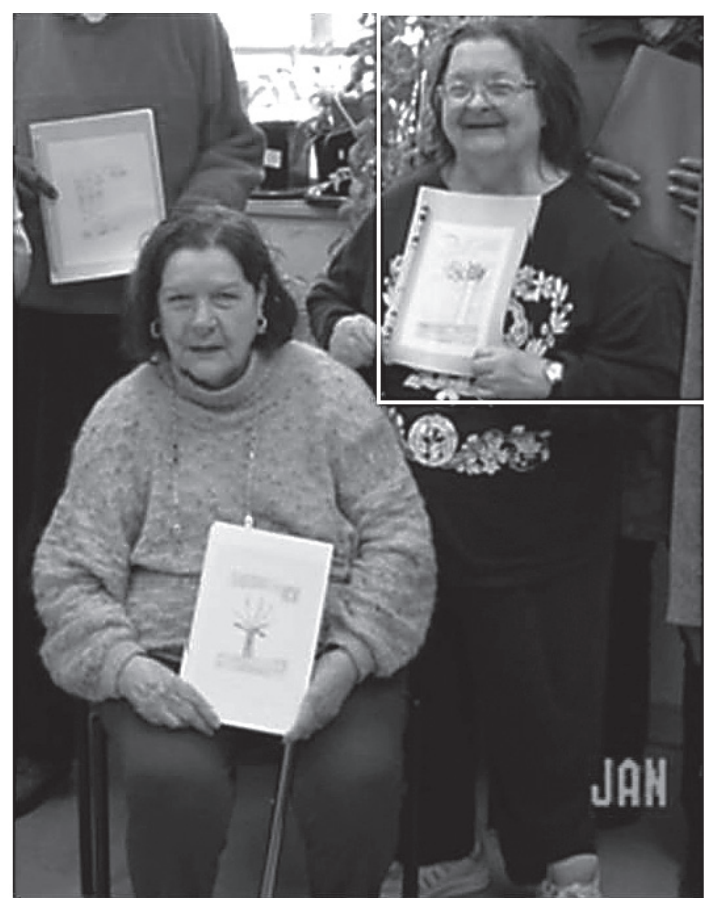

Source: 11/25, Portfolio (9 Jan. 2003). 
The threads of Doris' story all revolve around relationships; the good ones as well as the bad ones shaped her whole trajectory, including geographically. Her family, her friends as well as the mental health professionals are making her life conditions difficult, leading to her flight, or alternately they offer support - for which she is extremely grateful- and allow her to settle. Her story is infused with energy to live and fight; it lacks reflexivity, as the narrative that follows tries to convey.

Hard beginnings: "I wasn't meant to live" and "my mother didn't want me"

The story begins in 1929 in Mount Carmel, Illinois, where Doris grew up in a large family and with a mother who didn't want her, who told her so and treated her differently from the others since birth. Although Doris never understood her mother's stance toward her, she did live, despite it. After Doris starts working, quite young, her story "goes West" when she decides she wants to see something else and goes to work there. Here again, she follows her boss who is being nice to her.

\section{Moves and seclusions}

A few years later she comes back to Illinois, because she misses her family. She expects things to have changed but instead finds herself admitted to the asylum by that very family. She seems to stay in Illinois for a while, first for a couple of years in the asylum and then in a group home where she is so miserable that she plans her flight. She "goes East" this time, to Washington, DC, where she doesn't know anyone but finally settles. This is made possible by her stay at the immense St Elizabeth's psychiatric hospital. She insists repeatedly that people were nice to her in DC, and that in the asylum they "saved her".

Mental illness as an external object and psychiatry as a resource

What she means is that psychiatrists supported and helped her when her family and others let her down. After her escape, she went through some great hardships and found valuable support in Washington's psychiatric hospital, which she was grateful for and which helped her make it through. 
If Doris' story involved mental hospitals and doctors, mental disorder as an experience remained absent. She described her being in the asylum only as the result of complex family dynamics. Every action, feeling or situation she told me about featured a version of herself that was the same as who she was today. She didn't refer to being sick, or to distorted perception, or to any non-ordinary experience. Such an absence is quite common in narratives of persons who have been psychiatric patients. However we account for it (denial, memory loss, fear of stigmatization...), the fact that the 'mental illness hypothesis' is not evoked creates a void, something unspoken in our encounter.

\section{From being the devil to talking about Jesus}

Central to my relationship with John were his writings. During the art sessions, whatever the topic or task was, he would invariably spend his time writing on large white sheets of paper. In total, he wrote more than 50 small pieces, often with a title such as "my life" or "when I was young" but also "time" or "why". These pieces would tell about events and moments in his life as well as evoke God and Jesus. They were repetitive, yet all different. A few times, I was able to draw him into more formal interviews. He answered my questions and inquiries without ever giving up his main task of delivering the word of God. Thus I always had the feeling of incompletion, both in the sense that the narrative wasn't finished and of partial failure in trying to engage John into telling and reflecting about his life.

Figure 9 - John's booklet front side

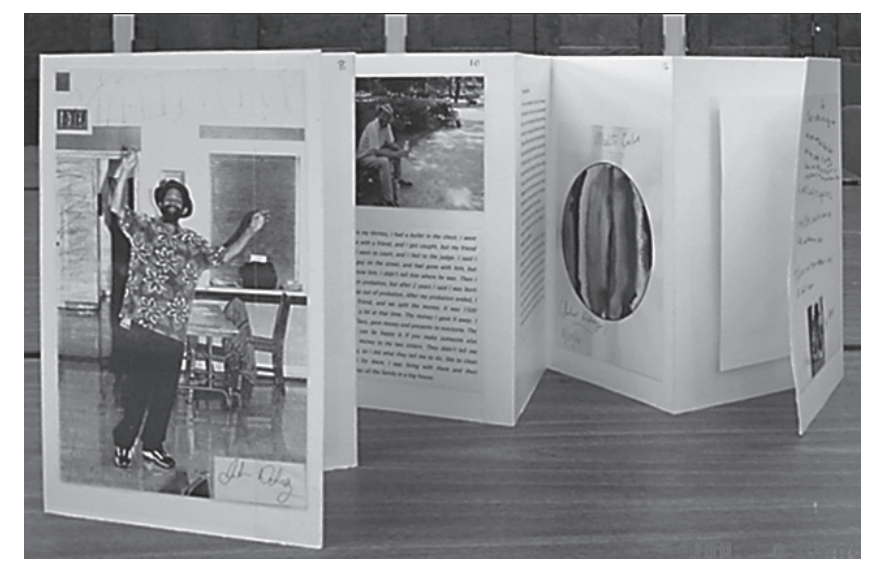

Source: 5/25, Portfolio (9 Jan. 2003). 
In the booklet, I used a lot of his pieces paired with extracts from our interviews, along with pictures of him and a colorful drawing he made, always associated with words. It thus came as a surprise to find out years later, going through his pieces again, that there was much less repetition and much more coherence than expected.

Figure 10 - John's booklet back side

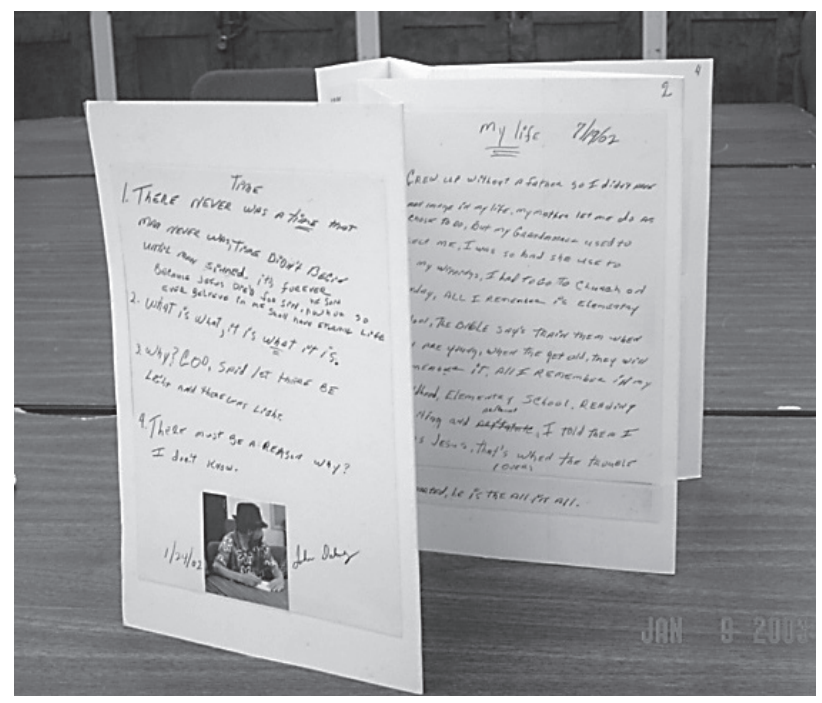

Source: 6/25, Portfolio (9 Jan. 2003).

"Once a man twice a child, Before you become a wise man first become a fool"

John's narrative was less developed than the other two, yet it is also quite coherent and can be told as a story. In the first piece John wrote when we started the project, titled "My life" (as many other would be), he more or less delineates the four periods John keeps referring to in all his writings. The first is when he was "Growing up"; he was cutting school and Church and smoking, although he notes that his grandmother, who raised him, did teach him "the right from the wrong". The second period is when he was in the Navy; there he saw the world but most of all he kept "being the devil", both drinking and gambling. His appreciation of that second period might be more ambiguous, though. At one point he explains how he "learned to be himself" when he was gambling. After his release from the Navy, due to 
an ear injury that leaves him partially deaf, John lives with various members of his family, working menial jobs and getting caught for a robbery which puts him in jail. The fourth period he describes starts with his admission to St Elizabeth's hospital, in DC. He is admitted because no one outside wants to listen to him when he talks about being God and using God's words. Thus, he appreciates being able to preach in the hospital, where, he says, "I thought good of myself, I thought Jesus, God and me. I still think so". He adds that "the patients would listen in the hospital. The psychiatrists wouldn't listen, I had to teach them".

\section{Ambiguous plots}

These words remind me of a young man I met a few years later, while doing research in France. During an interview, he said "What I can do is help [the mental health professionals]. If they are doing a good job and if they need my presence, if they deserved it, then I'm ok with being active, going to appointments, attending meetings and all" (Norbert). ${ }^{3} \mathrm{I}$ had found this a nice way to reverse the direction of the relationship and used it as an introduction to a chapter of my book. As is the case with John, such a stance did cohabitate with other, more compliant version of his role as a patient.

Figure 11 - Quote from John's lifestory 1

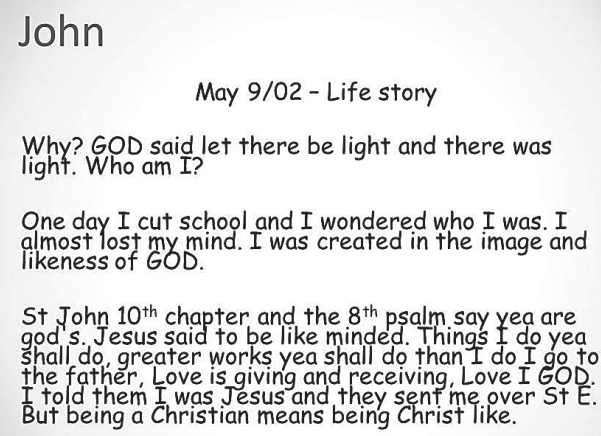

Source: personal files.

"Ce que je peux faire, c'est aider [les professionnels de la psychiatrie]. Si ce sont des gens qui font du bon travail, et s'ils ont besoin de ma présence, s'ils l'ont méritée, je veux bien être actif, aller aux rendez-vous, aux entretiens, aux réunions". 
Figure 12 - '(my Life)'

$$
\begin{aligned}
& \text { OrCE A mar Twice P Child, }
\end{aligned}
$$

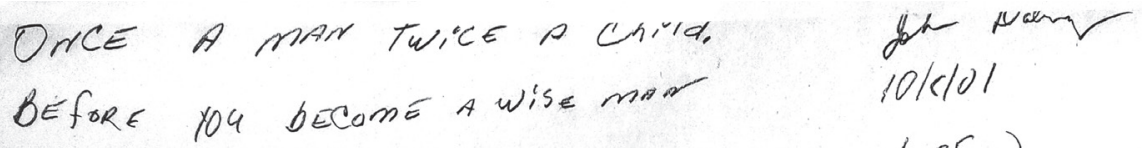

$$
\begin{aligned}
& \text { fiest become a fool. (MY LifE) } \\
& \text { When I waS a Little Child ny frordmothen told m } \\
& \text { I was Going to be a Preachen, whe I Grow ap }
\end{aligned}
$$

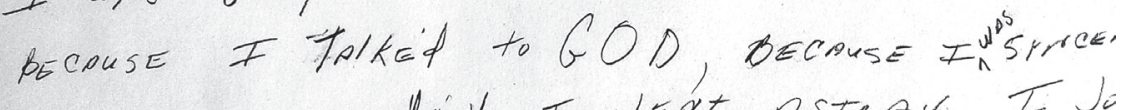

$$
\begin{aligned}
& \text { But whed she died I went pstery I Jo } \\
& \text { the dAJY Whed FWAS Ywerty Adel wedt h. }
\end{aligned}
$$

Source: excerpt from John's booklet, author's own copy.

Figure 13 - Quote from John’s lifestory 2

\section{John}

$$
\text { Oct-08/01 - My life }
$$

When I was a little child my grandmother told me I was going to be a preacher when I grew up because I talked to GOD, because I was sincere, but when she died I went astray.

I joined the Navy when I was twenty and went halfway around the world.

Then in my thirties I started preaching on the corner.

That's when the police told me to go home, I cursed them and the judge sent me over to Saint $E$.

$\cdot$

Source: excerpt from John's booklet, personal files.

John's story intertwines elements from his familial and social life and events with the history of his relationship with God, which he also presents 
as a quest to know who he is. His is a story of redemption, since he went from being the devil to acting like Jesus. Yet he keeps the ambiguity alive, alternately referring to his current God-like attitude quite literally, or at other times being explicitly metaphorical.

\section{The social experience of mental illness and its narratives}

\section{A social shaping of experience: the narrated, the embodied and the interacted}

The social experience of mental illness emerged as a notion to render the dynamics of long-term psychiatric care, especially outside of the hospital. I had observed these dynamics during the time I spent in community mental health care centers and discussed them in interviews with users of these services and professionals.

\section{Beyond binaries}

The social science literature on mental disorder is frustratingly polarized. On one side, the psychiatric institution and therapeutic practices are analyzed as a set of social forces shaping, controlling and dominating everything that relates to the illness, and as a consequence the person attached to it as well. On another side, a focus on the subjective experience of people suffering from mental disorder aims at rehabilitating the individual's agency and restoring his power, like for example his/her role in the management of the illness. Each pole thus emphasizes either the role of social institutions or the part played by the individual, crystalizing a much-criticized opposition. Lost somewhere between these two options, most often overlooked are the actual manifestations of the disorder that are experienced, which are embodied as well as shaped by various discourses, which in turn trigger social reactions and eventually mental health care.

The goal was then to take together all these elements, as they participate in the same dynamic, making the illness a composite set of what is said about it, what is seen as its manifestations: how it is perceived, explained, what is 
done about it and with it, what its effects are. It was equally important to integrate how people dealt with the embodied manifestations of the disorder as well as to place the relationship with the care providers within the person's broader set of social interactions. In other words, the idea was to avoid singularizing the "illness" dimensions from other aspects in the life of the individual.

Bridging different perspectives in medical anthropology (VELPRY, 2008a), the notion of social experience allowed for conceiving of mental disorder as a dynamic process, consisting of events, social constraints and resources that form the life trajectory. In this process, affiliation to psychiatry and its importance in everyday life as a resource depends on the availability of social and family resources, as well as on the ability to maintain different social inscriptions when confronted by disruptions (crisis, hospitalization) and while dealing with manifestation of the disorder.

The analysis radiates from the empirical individual, who embodies the manifestations of what is called mental illness. Yet these manifestations are shaped socially. Thus, starting with the empirical individual does not make the notion person-centered but rather allows for it to be fully embodied. (MOL, 2008) What is thus defined as mental illness logically varies across time for the same person. Considering illness as embodied by the individual thus allows letting go of a definition of mental illness as a stable entity. Attaching the disorder to the empirical individual allows for conceptualizing it both as a socially constructed object as well as a fluid set of states, situations, experienced behaviors.

The elusive narrative and the ethnographic fieldwork

With such a definition, the ways in which individuals conveyed this process become central methodological and epistemological concerns. Anthropologists have devoted considerable attention to narrative and subjective experience, to emphasize that it is far from self-evident. Eliciting a life story or a narrative is necessarily a situated coproduction. Meeting individuals because they belong to a psychiatric institution and have a diagnosis of mental illness frames the encounter. For example, one would expect that 
this fact is acknowledged or even accounted for in the narrative. Whether it is, or not, then becomes an object of interpretation.

Furthermore, a characteristic feature of mental disorder is that the individual will sometimes strongly deviate from the basic rules of interactions and of narrative, as a result of delusions of or cognitive impairments. As Goffman (1973) persuasively argues, it is precisely these deviations, along with the fact that their author does not acknowledged them - which would restore social order -, that trigger the hypothesis of a "mental problem". How is the researcher to deal with these deviations and how to integrate them in the narrative that is produced thus is also a concern?

Another caveat is that framing subjectivity is integral to mental health treatment. As I've detailed elsewhere (VELPRY, 2008b), this work is apparent in group sessions, where patients negotiate their "point of view", or some sort of subjective view, with the care providers, everyone walking a fine line between the obligation of the caretaker to protect their patient and his/her goal of fostering autonomy.

To deal with these concerns, the McClendon experience gives food for thought. Many situations (drawing and writing sessions, chats, activities, repeated interviews...) fostered or elicited a narrative (or expression) of some kind. This allowed for the reconstitution of multiple subject positions, as patient, as individual, as having a mental illness, as having to tell about their life and account for it. This was made apparent in the different narratives that Carryl, Doris and John's ways of responding to my offer to tell their story produced. Carryl's story is told as a reflection on his past life, oriented toward understanding how he ended up where he is now. Doris'story is a narrative full of the energy of fighting and is structured around successfully overcoming hardships. John's story tells about his redemption and his current missionary stance in life. I will now dwell on three recurring issues in the shaping of the stories: the presence of the disorder, the great importance of social expectations (whether one's own, family or the interlocutor's), and the interweaving of the social experience of mental illness with all the other dimensions of one's life. 
Figure 13 - John's booklet front cover

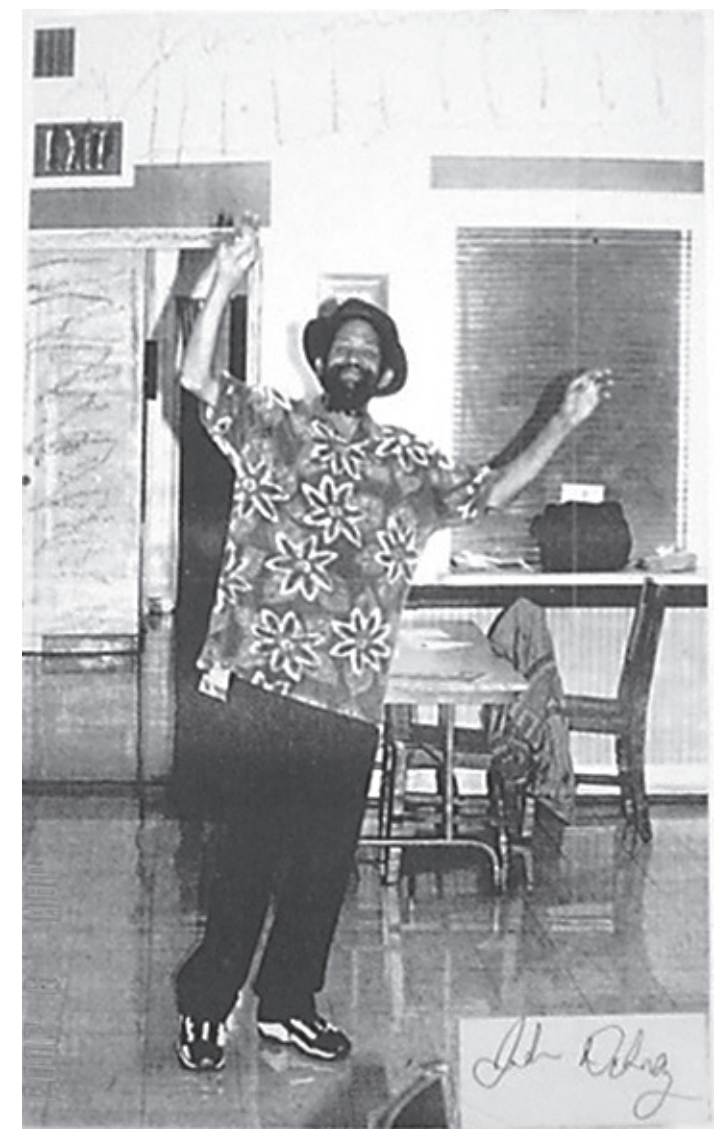

Source: 4/25, Portfolio (9 Jan. 2003).

\section{From the story to the social experience of mental illness}

Accounting for the illness

What is the illness and how does it appear (or not) in the way people recount their lives? Mental illness is present when we meet, albeit implicitly. The illness is why they are here and how I come to them, even if I never show any direct interest or address specific questions. Thus between us, as with the professionals of the center, as with the other residents, as with the family and friends, the illness has a social existence and even some agency. 
(WEINBERG, 2005) As a diagnosis, it was an administrative criterion for admission to the program and to access benefits or housing. Its manifestations might be involved in life disruptions and hospital stays, as well a trigger for taking medication. Yet the way this existence is acknowledged in the story and the extent to which it is incorporated in the experience varies a lot.

As I emphasized, Carryl was endlessly trying to determine the role that the disorder played in the path his life took, in relation to other elements. Every time we met for an interview, Carryl would discuss possible causes of the illness, its meaning and consequences. Which turn of events, in a life course, can be attributed to the illness? How do the ruptures and failures relate to the disorder, are the consequence of one's own character, childhood experiences, as well as social resources and opportunity? Weaving together all these components into a coherent narrative that explains how one got where he or she is, is a struggle. For Carryl, the narrative stayed unresolved, full of doubts and options; in the end it dominated most of our discussions. In so doing, Carryl was also voicing interrogations that were mine and unspoken, about the role his illness had played in his trajectory.

Accounting for the illness in her life didn't seem to be an issue at all for Doris. In fact, she never explicitly acknowledged that she had experienced something that could qualify as such. This saved her the effort of trying to make sense of the illness in her own life, leaving the resolution of this question to the listener. She did make the effort to give an alternative account of events that could be read as signs of a disorder by the listener. For example, her long stays in the asylum in her hometown were not associated with any illness narrative. Rather, they are fully incorporated in the narrative of her exclusion by her family, specifically her mother.

In other cases it might be settled, even if temporarily. John's account provides another option, since he does end up making sense of something that relates to the disorder. Yet, when active, it brings to the fore elements of the struggle.

The pervasiveness of the effects and signs of mental disorder can be apparent without any mention of is presence or absence of the individual experience and subjectivity. The way Doris never acknowledges it in her 
experience although she abundantly describes the asylums she was admitted to, is one example. Such is the case too when John subtly uses his delusional thoughts as a resource to define himself and his position, thus drawing our attention to the multiple uses that can be made of these manifestations.

\section{The enduring weight of social expectations}

Social expectations are another issue that is implicitly raised in the process of telling the story of one's life. They are more or less internalized or made explicit by others, professionals or family or strangers. They can be discarded but have to be dealt with. Very often, the people I met whose life had been disrupted by the manifestations of mental disorder and who had been in frequent contact with psychiatry, tried to account for the social downward mobility they underwent and for how it was produced. In doing so, they address the listener's implicit questions as well as their own. This involves sorting out the various causes, as Carryl is constantly doing. It also appears in the efforts made to justify the series of renouncements and adjustments that lead to the present situation. Carryl's job as a janitor in the hospital, for example, was not what he aspired to. Yet he describes it at as welcomed opportunity - that his mother opens - after having abandoned the university and lost jobs while being repeatedly hospitalized.

Mental health professionals often participate in this hidden discussion and adjustments, as they are involved in shaping the future. Thus, when the treatment goals include a "life project", it leads to a definition of what the acceptable social expectations are, at a given moment. When doing interviews with people I met through psychiatric services, I frequently felt their discourses played out the tensions in the process of adjusting previous expectations regarding their life and social status with their current situation, with the professionals acting as revealers.

This pressure was in part lifted at the Center. The shared frame of reference was that all the residents were older people, well over 60 , that they had a stable, supported way of life (housing, activities) and that they were not expected to display a personal project. In that sense, they were "beyond care" in the part that involves projects and social rehabilitation. In a way, 
it seems to me that the McClendon stories and experiences stand out from other research experiences I have had because its residents were out of the game. They didn't have to talk the project talk anymore, they might want to account for their lives, but basically it had played out, for good or for bad, in some cases with the associated cognitive damages. The injunction, on my and on their part, to define a future, or to narrate a past and a present that left some unknown, some openness for what was to come, was off.

\section{Illness narratives and life stories}

How does the social situations that go with the fact of "being in repeated contact with mental health professionals and institutions" interact with other dimensions and resources in life? How does it pervade, take the precedence over other social forces or recedes in the background? How does it act as a social force in a life course, in terms of resources (both providing them and drying them out)? These narratives show how, at the end of one's life, the signs of the illness and the contact with psychiatric care settings are leveled with other events in the life course, especially in a context of overall poverty. It is striking that psychiatry, and especially the asylum, constitutes a resource for social support, such as housing and employment, in several life stories.

But it is also sometimes a resource for social integration. In Doris' words, the mental health team in the hospital is granted a role of social integration in her new life. John also alludes to the respite that the hospital constituted in allowing him to keep preaching, when he was confronted to disbelief and rejection from his family and friends.

Finally, these stories allude as much to the ways of dealing with the disorder and with psychiatric care, as to the interweaving of historical events and social contexts with individual lives. The narratives evoke labor migration between the US and (a British colony in) the Caribbean in the 1930's; the self-consciousness of Carryl's blackness and its differences with the African Americanness in the US of the 1950's. Doris' young adult life talks about being white in rural, poor country towns, living in 
old-style asylums; she also is one case of the large migration from southern states to Washington, DC that occurred in the middle of the century...

Figure 14 - Last session in the activity room: discussing the booklets

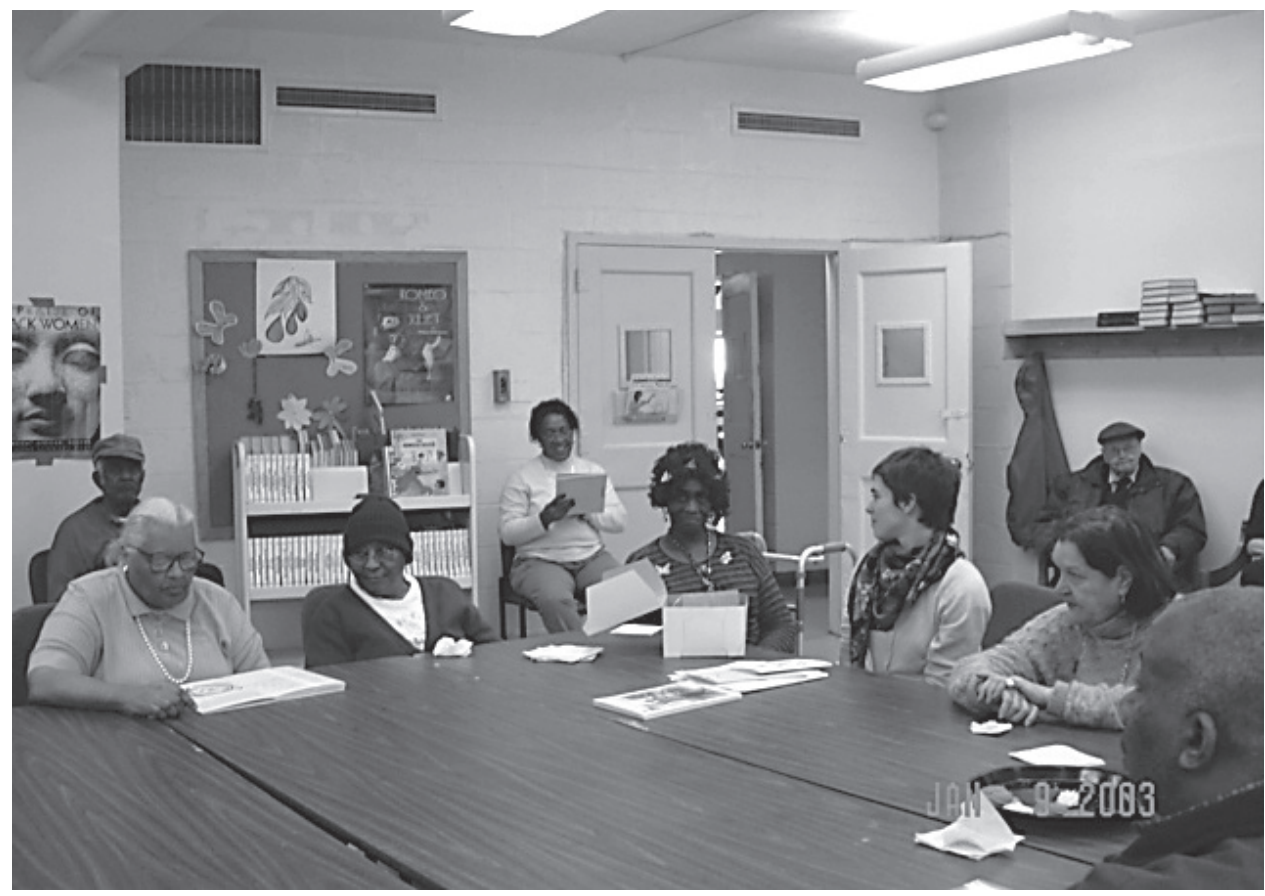

Source: 9/25, Portfolio (9 Jan. 2003).

I am not sure why it was so difficult, at the time, to put part of this experience into words. It might have been hard to understand what exactly had occurred. Or uncertainty on how to convey the bits I had grabbed. How was I to make sense of these interviews that left so many things of the lived life out and told about an era and a society I was not fully familiar with? How was it possible to convey in these narratives how much they were shaped by the way each resident related to me, a young French woman?

Bridging a reflexive account of a fieldwork experience, the thick description of life narratives and their production process, and an argument in an academic discussion, this contribution takes the risk of manifold incompletion. A common concern in these three threads is to explore alter- 
native legitimation practices, be it in the ethnographic encounter or in the production of narratives. The very notion of a social experience of mental illness could be criticized as legitimizing medical discourse and the social - and institutional - shaping of experience. On the contrary, being all at once narrated, embodied and interacted, this notion helpfully combines a subjective process with a molding by social forces that are indissociably tied to actual interactions.

As is stated in the two vignettes that open this contribution, during the whole project, arriving at the Center systematically triggered a contrasted feeling of depression and enthusiasm. On the one hand was the weight for me - of a ritualized life without a perspective of change. On the other was the alleviation of the institutional expectations regarding what should be achieved, even as a performative fiction. It combined with a genuine concern for the well-being and individualities of the residents. Producing a narrative was thus not taken in the institutional performance; nor was it academically constrained. The social experience of mental illness that emerges in the multifold narratives is infused with this context.

\section{References}

GOFFMAN, E. La folie dans la place. In: GOFFMAN, E. La Mise en scène de la vie quotidienne: 2. Les Relations en public. Paris: Les Editions de Minuit, 1973. (Collection Le Sens Commun).

MOL, A. The logic of care: health and the problem of patient choice. London: Routledge, 2008.

VELPRY, L. The patient's view: issues of theory and practice. Culture, Medicine and Psychiatry, Dordrecht, v. 32, n. 2, p. 238-258, 2008b.

VELPRY, L. Le quotidien de la psychiatrie: sociologie de la maladie mentale. Paris: Armand Colin, 2008a.

WEINBERG, D. Ofothers inside: insanity, addiction and belonging in America. Philadelphia: Temple University Press, 2005. 
